
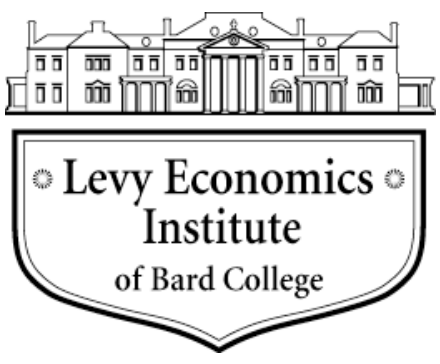

Working Paper No. 771

\title{
Foreign and Public Deficits in Greece: In Search of Causality
}

by

\author{
Michalis Nikiforos* \\ Levy Economics Institute of Bard College \\ Laura Carvalho \\ São Paulo School of Economics-FGV \\ Christian Schoder \\ Macroeconomic Policy Institute (IMK)
}

\section{August 2013}

\begin{abstract}
* For valuable comments and suggestions, we would like to thank Lance Taylor and Sebastian Gechert as well as the participants in the 39th Eastern Economic Association Annual Conference in New York. The usual disclaimer applies. Contacts: mnikifor@levy.org; laura.carvalho@fgv.br; christian-schoder@boeckler.de.
\end{abstract}

The Levy Economics Institute Working Paper Collection presents research in progress by Levy Institute scholars and conference participants. The purpose of the series is to disseminate ideas to and elicit comments from academics and professionals.

Levy Economics Institute of Bard College, founded in 1986, is a nonprofit, nonpartisan, independently funded research organization devoted to public service. Through scholarship and economic research it generates viable, effective public policy responses to important economic problems that profoundly affect the quality of life in the United States and abroad.

\author{
Levy Economics Institute \\ P.O. Box 5000 \\ Annandale-on-Hudson, NY 12504-5000 \\ http://www.levyinstitute.org
}

Copyright (C) Levy Economics Institute 2013 All rights reserved

ISSN 1547-366X 


\begin{abstract}
The paper discusses the trajectories of the Greek public deficit and sovereign debt over the last three decades and its connection to the political and economic environment of the same period. We pay special attention to the causality between the public and the foreign deficit. We argue that from 1980 to 1995 causality ran from the public deficit to the foreign deficit, but that due to the European monetary unification process and the adoption of the common currency, causality has reversed since. This hypothesis is tested and verified econometrically using both Granger Causality and Cointegration analyses.
\end{abstract}

Keywords: Greece, crisis, public debt, twin deficits, imbalances

JEL Classification: E62, F21, F34, F41 


\section{Introduction}

The Greek crisis of the last three years has occupied a central role in the public debates around the world. Prima facie, this is surprising for a country whose GDP is only a tiny fraction of the world or even European output. The antithesis between the small relative size of the Greek economy and its potentially vast repercussions highlights the high degree of complexity and interconnectedness of the world economic system and its financial institutions, and thus exemplifies the fragile and unstable state in which the global economy finds itself.

Moreover, the trajectory of the Greek economy over the recent decades can shed light to very important issues, such as the links between the economy and the social and institutional structure (political system, distribution of income, etc.); the influence of exogenous factors on the development of a small open economy; the prerequisites for a successful monetary union, and the role of financial markets in economic development.

In the present paper we seek to examine the evolution of the Greek public deficit and sovereign debt over the last three decades and its relationship to the political and economic environment of the same period. Understanding the accumulation of public debt requires a broader examination of the Greek economy, its position in the international economic system, as well as the goals and the actions of policymakers during the period in question.

Within this broader perspective, our specific objective is to analyze the direction of causality between the foreign and public deficits in Greece from 1980 to 2010. The typical narrative emphasizes the high degree of tax evasion and the "profligacy" of the Greek state as the main factors that caused the accumulation of public and foreign debt. Indeed, Greece entered the crisis of 2008 with the highest debt to GDP ratio among the economies of the European Monetary Union, and had together with Italy, the highest level of tax evasion and the biggest shadow economy within the EMU (Schneider 2011). This evidence has been often used to support the exogeneity of the Greek fiscal deficit, and by means of the so-called "twin deficit hypothesis", its leading role in causing a deterioration of the country's current account. If one accepts this general argument, strong fiscal austerity measures are needed to help solve both the fiscal and external imbalances in Greece.

A different approach maintains that the main source of the problem is to be found in the structural characteristics of the EMU and the global economic recession of the last five years. This argument was made stronger after other countries such as Portugal, Ireland and Cyprus had to be bailed out, and Spanish and Italian bond yields also increased to unsustainable levels. An answer to this puzzle can be found in the structural deficiencies of the EMU. The euro area does not meet the criteria of an optimum currency area theory. ${ }^{1}$ The problem was further exacerbated by divergent paths of

\footnotetext{
${ }^{1}$ See Mundell (1961), Kenen (1969). Krugman (2012) provides a discussion of the theory in relation to the current crisis in Europe. De Grauwe (2012) summarizes the debate on the Economics of [a] Monetary Union.
} 
the cost of labor and inflation in different countries of the currency union.

According to this explanation countries with high productivity have gained a permanent competitive advantage over countries with low productivity, which is translated into "quasi-structural" foreign deficits for the low productivity countries. These imbalances are translated into a "quasistructural" foreign deficit for the low productivity countries. Simple accounting dictates that this deficit has to be matched by a deficit in the domestic sector-either by the government or the private sector. From this point of view, the accumulation of the Greek government debt (or the bubbles in the private sector in Ireland and Spain) could be seen as the result, rather than the cause of the imbalance.

The two opposing views on the relationship between fiscal and foreign deficits suggest different kinds of policies for the solution of the Greek and European crisis. One view proposes austerity - and the removal of the various domestic "frictions" - as the way out. Another view points towards the need for further financial, fiscal and political integration and coordination which will focus primarily on these external imbalances (or a complete disintegration with the exit from the euro).

The examination of the data and the economic history of Greece of the last three decades leads us to the formulation of the hypothesis that the causality was runing from the foreign to the public deficit in the period 1980 until 1994. However, since 1995, because of the European monetary unification process, the adoption of the (so-called) hard drachma policy and then the adoption of the common currency the causality has reversed. We test this hypothesis with a series of econometric techniques; both the Granger causality tests and a Cointegrated Vector Autoregression analysis verify this change in the direction of causality.

The paper is organized as follows. In the next section, we discuss the theoretical foundations of the relationship between the deficits of the three institutional sectors, public, private and foreign. We explain how different theories point to different directions of causality and different channels of transmission. In section 3, we discuss the evolution of the Greek public debt in relation to other basic macroeconomic indicators and explain how these are related. In section 4, we state our hypothesis that the causality between the foreign and the public deficit has changed in the mid-1990s. We provide a brief overview of the economic history of that period and the factors that lead us to believe that our hypothesis is valid. In section 5, we test our hypothesis with statistical methods. Section 6 concludes. 


\section{The Relationship between Foreign and Government Deficits}

\subsection{Accounting and closures}

Accounting implies that the current account balance, $C A B$, as defined by the sum of the trade balance, $X-M$, and the net amount of income, $N Y$, and current transfers from abroad, $N C T$, is equal by identity to the difference between gross domestic saving $S$ and investment $I$, or more generally to the difference between gross national disposable income and expenditure on goods and services by domestic residents. In other words, it is only possible to achieve an improvement in a country's current account by means of an increase in national income that is not matched by a commensurate rise in domestic absorption (defined as the sum of consumption, investment and government spending). Hence,

$$
C A B=X-M+N Y+N C T=S-I .
$$

Alternatively, as formulated by Godley and Cripps (1983) and Steindl (1990), the sum of net borrowing flows, as defined by the difference between expenditure and gross disposable income of the private sector, the government and the foreign sector, must be equal to zero, so that the current account deficit (or net lending to the rest of the world) can be expressed as the sum of private and public net borrowing, denoted as $N B_{P}$ and $N B_{G}$, respectively:

$$
-C A B=N B_{P}+N B_{G}
$$

Different closures $^{2}$ have been applied to such accounting relationships in economic literature, each of them implying in a set of causal channels and adjustment mechanisms involving the variables in question. In particular, theoretical approaches based on a loanable funds theory of the interest rate support the idea that any initial imbalance between domestic savings and investment will be met by net financial flows. In other words, a current account deficit, as expressed in (1) by an excess of investment over domestic savings flows, would drive the interest rate up in the market for loanable funds, which would help attract financial inflows (foreign saving) to finance the initial deficit. In terms of equation (2), this idea can easily translate into the argument that a positive shock in the government deficit may create excess domestic expenditure over disposable income, also driving up interest rates and attracting foreign capital. The inflow of foreign capital would in turn lead to an ap-

\footnotetext{
${ }^{2}$ The terminology of closures has been popularized by Taylor and Lysy (1979) to denote the set of variables that are considered endogenous and exogenous and the different causalities that can be placed in a set of restrictions or simple economic relations.
} 
preciation of the exchange rate, causing a deterioration of the trade balance. This causal structure is precisely the one that underlies the first version of the so-called "twin deficit hypothesis", as stated by Volcker (1984) and Abell (1990) in the context of the current account and fiscal imbalances of the United States in the 1980s.

In addition to responses of the interest rate in the loanable funds market and the increase in net capital flows, which are central to the Mundell-Fleming model, theoretical arguments in support of a twin deficit are sometimes based on changes in relative prices. According to this transmission channel, a fiscal expansion would increase domestic demand relative to output, with a positive effect on domestic prices. The consequent real appreciation of domestic goods relative to foreign goods would crowd out net exports, assuming that the Marshall-Lerner conditions are satisfied. ${ }^{3}$ The deterioration in the current account could be even stronger if one also considers the leakage of the initial increase in domestic demand abroad, via imports, or weaker if private investment is partially crowded out by the hike in interest rates. In this context, some authors argue that the external impact is higher for spending hikes than for tax cuts.

The traditional debate on the existence of "twin deficits" has opposed the above-mentioned mechanism, which some authors (inappropriately) call the "Keynesian view", to an inter-temporal "Ricardian View" of consumption behavior. In the latter, with the interest rate as constant and labor supply as fixed, infinite-horizon optimizing households respond to any permanent increase in government spending by reducing consumption by the exact same amount. As in the Ricardian equivalence principle stated in Barro (1974), the idea is that consumers know in this case that they will have to carry the burden of an increase in public spending in the future, and thus reduce private saving in the present accordingly. It is clear that no external impact of a higher fiscal deficit would be observed in this case, contradicting the "twin deficits" hypothesis.

However, in the same optimizing framework, if the increase in government spending is taken to be transitory, private saving may not react, causing the current account balance to fall almost oneto-one. This type of justification for the existence of a twin deficit can be thought of as a weaker variant of the permanent income hypothesis. In other words, the idea is that in response to a higher public deficit, current consumption may fall, but less than one-to-one, since permanent income is assumed to only adjust by the permanent increase in taxes required to satisfy government solvency. The country borrows from abroad to close the gap in national saving, which converts into a current account deficit. This mechanism is the basis of the so-called small open economy view, which suggests that budget deficits reduce national saving, but that international capital inflows finance the entire reduction. Budget deficits in this case would increase borrowing from abroad and thus reduce future national income, but would not affect interest rates or future domestic production.

\footnotetext{
${ }^{3}$ This price mechanism can be thought of as an application of the forced savings mechanism to an open economy setup.
} 
This idea was later criticized in the recent New Open Economy Macroeconomics (NOEM) models of Obstfeld and Rogoff (1995) and Betts and Devereux (2000), in which permanent government spending increases may be associated with an improvement of the current account. In these models, for a given persistence of the fiscal shock, the more closed an economy, the larger the crowding-out effect of government spending on investment and the lower is the deterioration of the trade balance. This argument gave rise what became known as the twin divergence hypothesis.

All these views contrast with those of Steindl (1990), who by considering autonomous components of effective demand (business and household investment, exports and government spending) as pre-determined, argues that both the foreign and public sectors act as stabilizers of the private sector's behavior. An increase in business investment would lead to an increase in GDP, which is absorbed by higher leakages in the government and foreign sector (in the form of an increase in tax revenues and imports). The same stabilization mechanism would be launched when investment is reduced: the resulting lower GDP would convert into public and foreign sector's surpluses (as imports and taxes go down).

Steindl (1990)'s closure is compatible with the absorption approach used in so-called gap models, in which the type of adjustment mechanism in equation (2) depends on which of three gaps foreign exchange, savings and fiscal - is binding. ${ }^{4}$ In this context, it is often considered that in small open developing economies, it is national income that adjusts to keep domestic absorption and the current account deficit in balance, or at a level which can be financed by an exogenously determined amount of net capital flows available. In this case, it is clear that the abundance of capital inflows could allow for higher domestic — particularly, government—spending and, thus, for a higher GDP level, as will be discussed later in the Greek context. This argument is further developed in the literature based on balance of payments constraints on growth (see for instance Thirlwall and Hussain (1982)).

Besides working through fluctuations in GDP and automatic stabilizers, causality may run from the current account to the budget deficit as a result of active policy. First, as highlighted by Summers (1988), governments in some countries have used the budget policy for external adjustment in what the author calls "current account targeting". Second, in what seems to be more relevant to the Greek case, when external finance was available, policymakers may have responded with higher government spending to "domestic hardships" caused by the trade balance, as a way to avoid recessions (see Abell (1990) for this interpretation). In other words, in the latter context the government has the objective of maintaining the GDP level or the growth rate of the economy when there is a deterioration in the trade balance, and actively pursues expansionary fiscal policy for this purpose. As will be described in the next section, this type of stabilization policy can be facilitated by the availability of capital inflows and low borrowing costs.

\footnotetext{
${ }^{4}$ For a review of gap models, see Taylor (1994).
} 
In fact, even if it starts from a loanable funds theoretical framework, the Balance of Payments Manual published by the IMF (1999) states that whenever the increase in the interest rate following an excess in domestic expenditure is insufficient to attract the amount of net financial flows that are necessary to finance it, three options of adjustment of the balance of payments present themselves to the government in question:

1. Use of reserve assets for balance of payments financing (this option is limited by the amount of reserves held by the country);

2. Policy actions to attract private funds;

3. Other adjustment measures by the government, such as contractionary fiscal and monetary policies, which would serve to eliminate the excess of investment over savings, or exchange rate depreciation.

Conversely, if foreign savings are more than sufficient to compensate for an initial current account deficit at home, there would be overall excess savings (domestic and foreign) relative to investment, driving down the interest rate and increasing interest-sensitive components of domestic spending, as well as the space for expansionary fiscal policy, which, as above-mentioned could be used for stabilization purposes.

In short, economic theory has provided different channels of causality between the fiscal deficit and the current account deficit. On the one hand, if the fiscal deficit is taken as an exogenous variable, it can drive the current account deficit: (1) by creating excess (or insufficient) domestic savings, both directly and/or via changes in private expenditure, which could cause interest rates to respond and movements in foreign savings; or (2) by leading to pressures on prices and the real exchange rate, thus reducing net exports. On the other hand, if the foreign deficit is taken as exogenous, or structural, the fiscal deficit can be the adjusting variable. It can do so by two different channels. First, if automatic stabilizers are taken into account and the principle of effective demand is assumed, tax receipts and some components of government spending can respond to the GDP level and its other components, including the trade balance. Second, reverse causality between the two deficits can also arise from policy decisions. Specifically, the government may pursue expansionary fiscal policy so as to avoid a fall in GDP when the trade balance deteriorates. Finally, it is clear the adjustment of the fiscal deficit to the current account deficit for stabilization purposes-being it automatic or active - is only feasible when there is a sufficient inflow of foreign capital and the government can borrow at a relatively low interest rate. 


\subsection{Empirical evidence}

Most studies of the relationship between fiscal and external deficits have searched for a unidirectional causal relationship running from the budget deficit to the current account deficit in the US and other countries, both directly and through other variables. The seminal study in support of the "Keynesian view" as an explanation for the twin deficits in the United States in the 1980s is that of Abell (1990), which shows by means of a VAR model that increases in the fiscal deficit led to an appreciation of the currency (through the interest rate linkage), and thus to a deterioration of the trade deficit. More recently, Salvatore (2006) has provided evidence of a direct (lagged) relationship between budget and current account deficits for all G-7 countries in the past three decades.

Recent studies have also found empirical evidence against the twin-deficits hypothesis. Erceg et al. (2005) find that the fiscal deficit has a relatively small effect on the trade balance in the United States: a rise in the fiscal deficit of one percentage point of GDP induces the trade balance to deteriorate by 0.2 percentage point of GDP or less. As highlighted in Barbosa-Filho et al. (2008), since the early 1980s there has been a strong correlation in the trends of household borrowing and foreign net borrowing (the current account deficit) in the US. The authors argue that these were the true twins in the US economy, with the public deficit acting as the residual.

As highlighted by Corsetti and Muller (2005), empirical estimations of the twin-deficit hypothesis are often biased by the cyclical component of both the fiscal and the trade deficit: an upsurge of economic activity would typically improve the fiscal outlook (via automatic stabilizers), while worsening net exports due to higher import demand, which could lead to a negative correlation between the two. Kim and Roubini (2008) have estimated VAR models that take into account the cyclical component of both the fiscal and the trade deficit by controlling for changes in GDP and conclude that government budget deficit shocks have generally improved the current account and depreciated the real exchange rate in the US, explaining a twin divergence. Corsetti and Muller (2005) extend the VAR estimations to four countries and argue that in the US and Australia, which are relatively less open to trade than Canada and the UK, the external impact of fiscal policy is rather limited, mainly due to a decrease in domestic private investment following higher deficits.

The empirical study in this paper aims to answer a different question: What was the main direction of causality in the relationship between current account and fiscal deficits in Greece since 1980. Given that one of the two possible mechanisms for reverse causality provided in the last sub-section depends precisely on the cyclical components of government revenues and expenditures, automatic stabilizers will not be excluded from the analysis.

Along these lines, the study by Vamvoukas (1999) examines trivariate causality tests for the trade balance, the fiscal deficit and either real output or the inflation rate in Greece from 1948 to 1994, and concludes that there was a predominantly unidirectional causality running from the budget deficit to the trade deficit in both the long- and short-run during that period. However, the more recent study 
by Baharumshah et al. (2006) found a two-way causality relationship for the vast majority of countries in their sample. The exception in their study is Indonesia, where the only direction of causality seems to be from the current account to the fiscal deficit, which the authors interpret as evidence of "current account targeting" by the government. In this context, the possibility that the predominant channel of causality between fiscal and trade deficits has reversed in Greece after 1995 is analyzed historically and empirically in the following sections.

\section{The Greek Public Debt from a Historical Perspective}

\section{1 (More) Accounting Identities}

We can start the discussion of the trajectory of the public debt and deficit with some basic accounting identities that link the accumulation of debt with the deficit, the growth and interest rate and inflation.

By definition each period $t$ the public debt is equal to the debt of the previous period plus the deficit of the current period. More formally

$$
D_{t}=D_{t-1}+b_{t}
$$

where $D$ stands for government debt and $b$ for the government deficit. The subscript denotes the period each variable refers to. Stated differently, equation (3) can be rewritten as

$$
\Delta D_{t}=b_{t}
$$

where $\Delta$ is the difference operator. In turn the government deficit is equal to the the primary deficit and the net interest payments, the payments of the government to the holders of the public debt

$$
b_{t}=b_{t}^{p}+b_{t}^{n i p}
$$

where $b^{p}$ is the primary deficit and $b^{n i p}$ the net interest payments. The latter depend on the stock of debt of the previous years and the interest rate paid on this debt. More precisely

$$
b_{t}^{n i p}=j_{t} \times D_{t-1}
$$

where $j$ is the implicit interest rate, a weighted average of the interest rate on the government bonds of different maturities. 
By combining equations (4), (5) and (6) we get

$$
\Delta D_{t}=b_{t}^{p}+b_{t}^{n i p}=b_{t}^{p}+j_{t} \times D_{t-1}
$$

Equivalently, the change of the debt to GDP ratio is equal to

$$
\Delta(D / P Y)_{t}=\left[b_{t}^{p}+\left(j_{t}-g_{t}-\pi_{t}-\pi_{t} g_{t}\right) \times D_{t-1}\right] / P_{t} Y_{t}
$$

where $Y$ stands for the real GDP, $P$ for the price level, $g$ for the growth rate of the real GDP and $\pi$ for the inflation rate.

Equation (8) shows that - ceteris paribus - an increase in the primary deficit and the interest rate and a decrease in the growth rate and the inflation will tend to increase the debt to GDP ratio. Therefore, understanding the accumulation of debt normalized to GDP requires the analysis of the trajectory of the primary deficit, the interest rate and the growth and the inflation rate. We take up this task next.

\subsection{Debt and Growth}

Figure 1 presents the the debt to GDP ratio and the growth rate of the real GDP of the Greek economy for the period 1960-2010. ${ }^{5}$ Figure (1a) presents the trajectory of the Greek debt for the same period. In 1960 the debt to GDP ratio was around 10\%. Between 1963 and 1973 this ratio fluctuates around 20\%. The Greek debt starts increasing in the mid-1970s with an increasing rate. The debt to GDP ratio increases from $16.6 \%$ in 1973 to $97.6 \%$ in 1993 . The rate of increase slows down in 1992 and the debt to GDP ratio stops increasing in 1996, when it stabilizes around 107\%. A slight increase in 2008 is followed by the implosion in 2009 and 2010.

Figure $1 \mathrm{~b}$ shows that the Greek economy follows the growth patterns of most economies in the world. The first decade, until the late 1960s is marked by high rates of growth. This pattern is interrupted in the early 1970s. In the late 1970s there are again some years of low growth. The years between 1980 and 1994 are characterized by a significantly lower average rate of growth compared to the preceding two decades. In the last half of the 1990s and the first seven years of the 2000 s the Greek economy grows at an average rate of around 4\%. Beginning in 2008 the growth rate slows down. In 2009 the growth rate was negative (-2.04\%) and in 2010 reached $-4.5 \%$. 


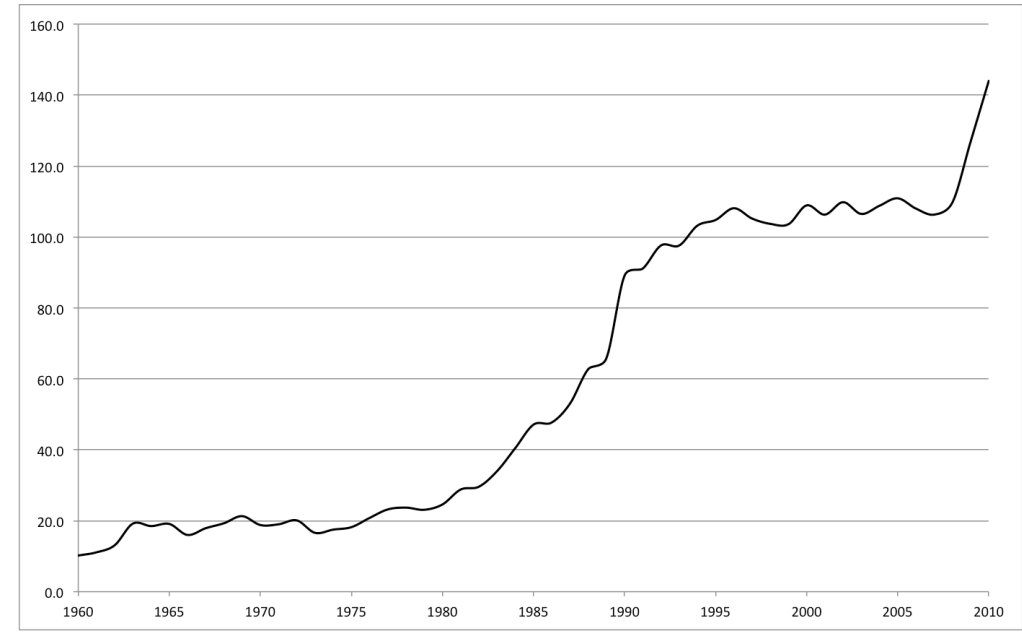

(a) Public Debt to GDP ratio

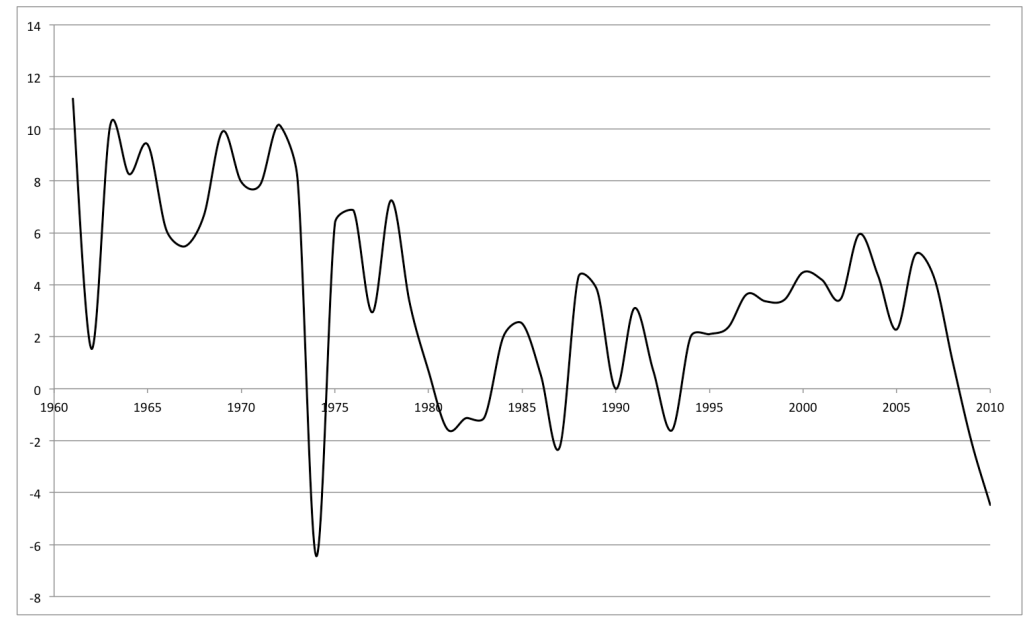

(b) Real GDP growth rate

Figure 1: Debt to GDP ratio and Real GDP growth rate(1960-2010)

\subsection{Government Deficit and its decomposition}

The dynamics of the Greek public debt can be further understood with the help of figure 2, which presents the government deficit and its decomposition into primary balance and interest payments for the period 1970-2010. In the 1970s the deficit hovered around 2.3\%. During this period, there is a steady increase of the net interest payments, which reach $1.7 \%$ in 1980 . The deficit jumps in 1981, an election year. The total deficit increases by almost $5.5 \%$ that year. The primary deficit is responsible for almost $5 \%$ of that increase. The primary deficit continues to hover around 4.5 for the rest of the decade. However, the burden of net interest payments is increasingly heavy and as a result the total deficit is increasing. The 1990s is a decade of fiscal consolidation. 1994 is the first year with a primary surplus after more than two decades. The primary balance remains positive un-

\footnotetext{
${ }^{5}$ The sources for the data of section 3 can be found in the Appendix.
} 


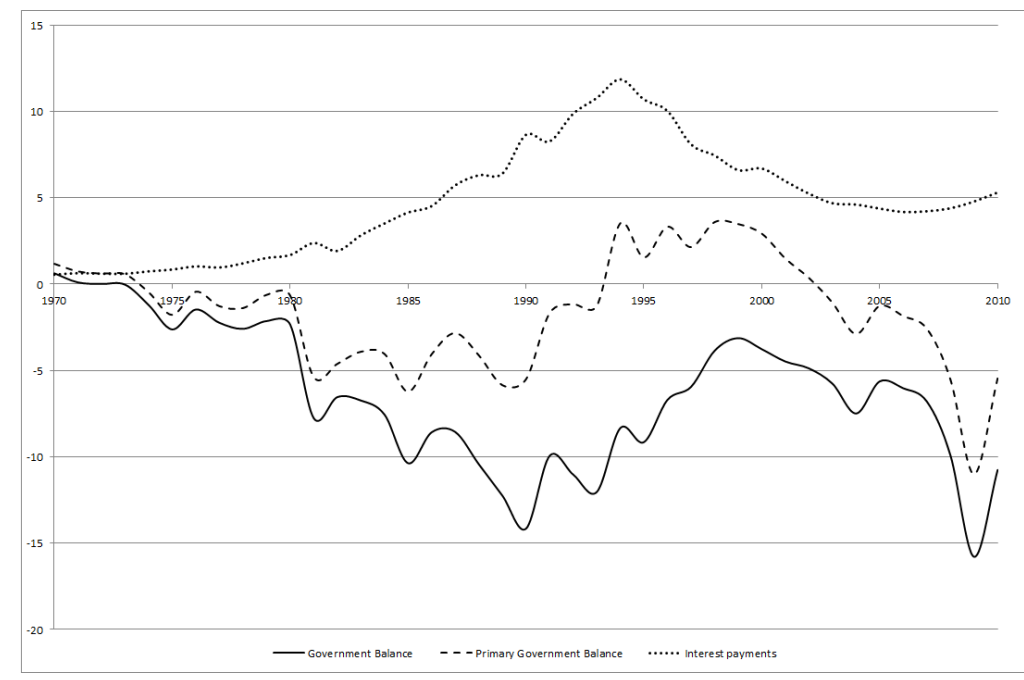

Figure 2: Decomposition of the government deficit (1970-2010)

til 2002. The burden of the net interest payments kept increasing until 1995 and de-escalates after that, mainly due to the fall of interest rates. The high interest payments led to government deficits of more that $3 \%$ even when the primary surplus is more than $3 \%$. In the 2000 s the interest payments stabilize around $4.5 \%$. However, at the same time there is a deterioration of the primary balance. 2003 is the first year after ten years with primary deficit, which further increases in 2004 - the year of the Olympic games of Athens. After a small decrease in 2005 and 2006 the deficit collapses after 2007 and reaches 15.7\% in 2009. 2010 is the first year of the Memorandum of Understanding with the so-called "troika" (i.e. European Commission, European Central Bank and IMF) and of austerity.

An interesting characteristic of the behavior of the primary and total deficit is that in the period prior the mid-1990s it increases at the election years. 1981, 1985, 1989 and 1990 (there were three elections in these two years) and 1993 are all election years. The elections of 1993 were followed by two elections (1996 and 2000) without a visible increase in the deficit. An increase of the deficit during an election year can be observed again in 2004 (although it is not clear to what extent this increase is due to the outlays for the Olympic games of that year) and the period after that.

Another important dimension for understanding the trajectory of the debt is the interest rate, which the government has to pay for servicing its debt. As we showed in equation (6) the net interest payments of the government for each year are equal to the total debt of the government the year before times an implicit interest rate, which is a weighted average of the yield of government bonds of different maturities.

Equation (6) can be solved for the implicit interest rate and thus by utilizing the data we presented above we can calculate it. Figure 3 presents this implicit interest rate for the period 1970 to 2010, together with the series for the GDP growth and the Federal Reserve effective interest rate. As 


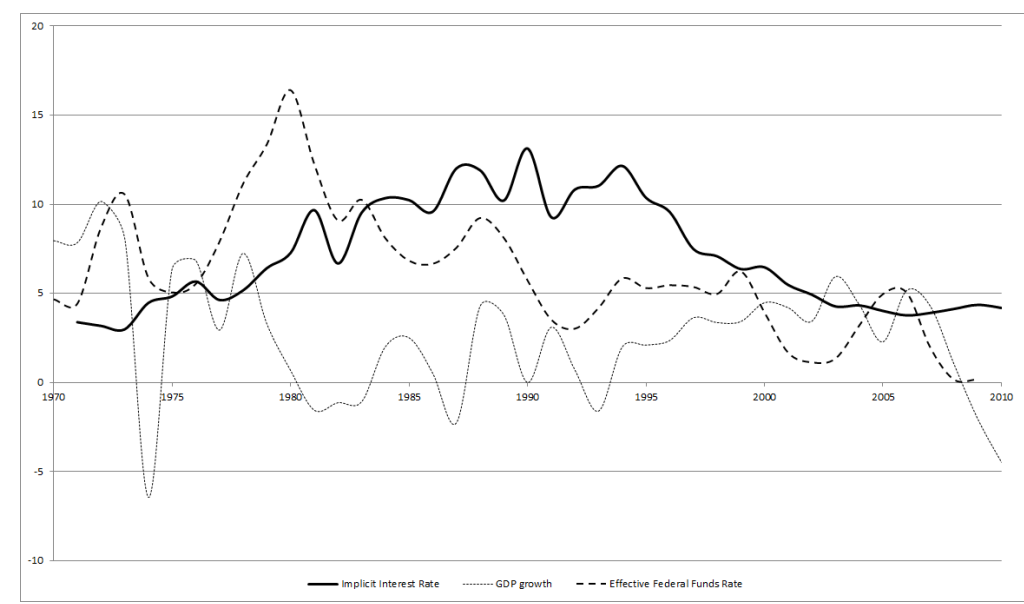

Figure 3: The GDP growth rate, the implicit interest rate and the effective interest rate of the FED (1970-2010)

we can see the implicit interest rate increases until the early 1990s and after a period of stability in the first half of that decade decreases to slightly below $4 \%$ in the 2000 s.

An important part of the behavior of this interest rate can be explained by the conditions that prevailed in the global economy and can be considered as exogenous to a small economy like Greece. A detailed analysis of this issue is complicated because of the obvious endogeneity issues and goes beyond the scope of this paper, however it is obvious that the increase of the implicit interest rate until the late-1980s is related to a large extent to the high interest rates that prevailed at the time due to the policy of the Federal Reserve in the US. For example, although in the years up to 1976 there is no increase in the debt-to-GDP ratio the implicit interest rate almost doubles.

The evolution of the total debt, as presented in figure 1a, can thus be understood through the discussion of figures 2 and 3. The change of government debt as a percent of GDP (figure 1a) can be understood as a function of the primary deficit as a percent of GDP (figure 2), the net interest payments (figure 2 again) and the growth rate of the GDP (figure 1b). The term $j_{t}-g_{t}$ can be visualized as the distance between the implicit interest rate and the growth rate lines in graphs in figure 3 . Besides the increase in the cost of lending the global economy experienced a slowdown of growth after the mid-1970s. To the extent that this slowdown affected the growth rate of the Greek economy, this slowdown played a similar role with the increase of the interest rates in the increase of the debt to GDP ratio during that period.

\subsection{Inflation}

Figure 4 presents the trajectory of inflation over the last five decades. Inflation is below 5\% in the first period of our sample. The energy crisis of 1973 sent inflation to $21 \%$ that year and almost $23 \%$ the year after. The second energy crisis of 1979 sent again the inflation above $20 \%$. Inflation peaked 
in 1982 slightly above $27 \%$ and then receded slowly for the rest of the 1980 s to reach $14.5 \%$ in 1989 . After a jump in 1990 when it passes $20 \%$ again, a decade of rapidly decelerating inflation follows. In 1999 inflation reached 3\% and remained around that level for the next decade.

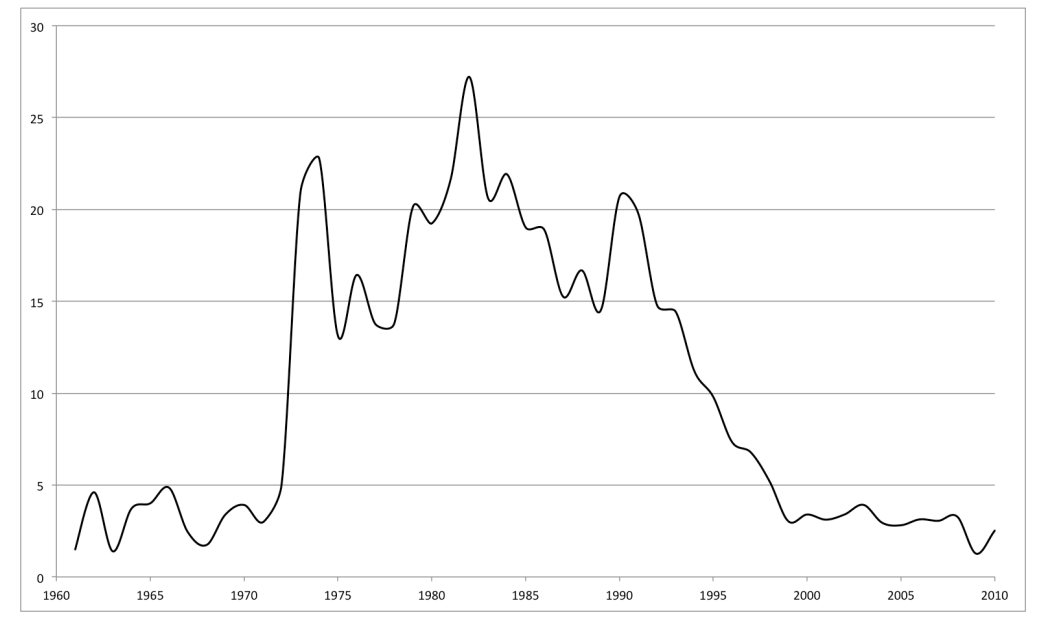

Figure 4: Inflation rate (GDP deflator)for the period 1960-2010

The examination of inflation rate is important because starting with the signing of the Maastricht Treaty a stable and low inflation rate becomes the main focus of economic policy in Europe and Greece. According to Article 109j of the treaty the first criterion that an aspiring member of the common currency should meet is "the achievement of a high degree of price stability; this will be apparent from a rate of inflation which is close to that of, at most, the three best performing Member States in terms of price stability". This criterion is then specified in detail as "an average rate of inflation,...that does not exceed by more than $1^{1 / 2}$ percentage points that of, at most, the three best performing Member States in terms of price stability". 6

The economic rationale behind this focus on low inflation is well known. Neoclassical economic theory is tells us that in a world with rational expectations, unemployment will always be at its natural level and any effort to lower unemployment below that level will only create inflation. This is the famous rules rather than discretion argument made by Kydland and Prescott (1977) and Barro and Gordon (1983).

The rest of the Maastricht criteria, as well as the institutions of the European Monetary Union were built around this target of low inflation. For example, the second criterion of low government deficit (below 3\%) or the call for a conservative central banker are the textbook policy conclusions of the aforementioned economic models. They create an institutional structure that prohibits discretionary policy. ${ }^{7}$ After the Maastricht Treaty the fiscal, the monetary and as we will see below, the

\footnotetext{
${ }^{6}$ The full text of the treaty of Maastricht can be found at http://eur-lex.europa.eu/en/treaties/dat/ 11992M/htm/11992M.html.

${ }^{7}$ For a more detailed discussion see Obstfeld and Rogoff (1996, ch. 9) and De Grauwe (2012).
} 
exchange rate policy focus on the maintanance of a low inflation rate.

Figure 4 shows that Greece made a serious effort to meet the inflation criterion, and that by historical (and by almost any other) standards it achieved a very low inflation rate after the late 1990s. Still, this inflation rate, which reflected the trajectory of the nominal wages, was high compared to the inflation of the European core; for example, German inflation in the period 1998-2007 never exceeded $2 \%$, with most of the years being below $1 \%$.

\subsection{Net Lending}

As we explained in section 2 above (equation 2) the government deficit has to be matched by net lending flows from the other institutional sectors of the economy.

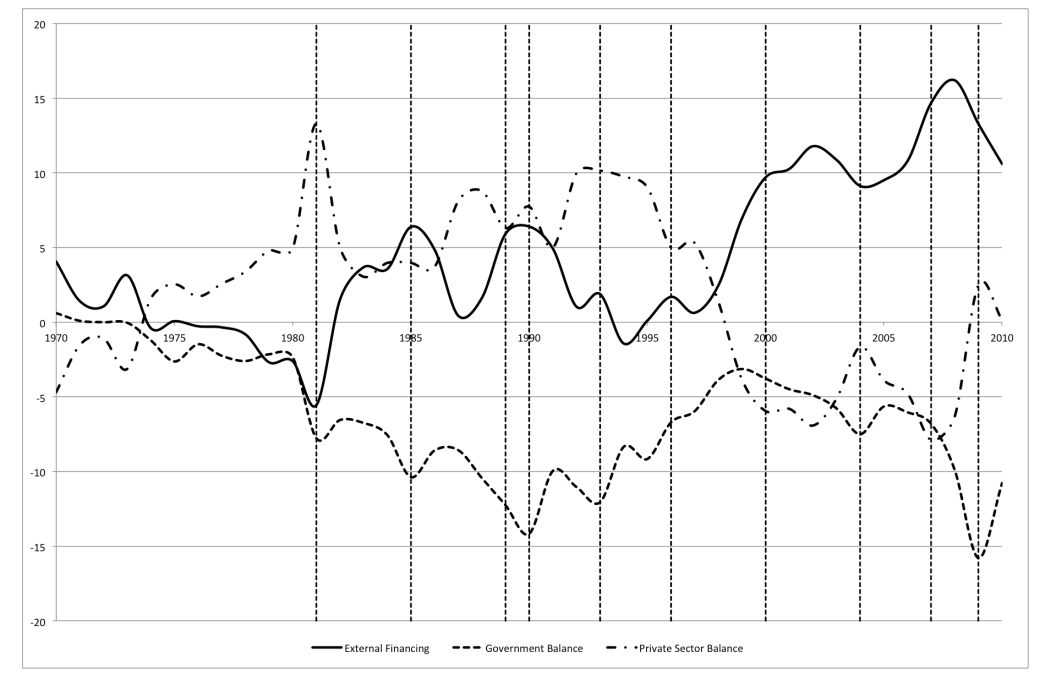

Figure 5: Resource gap by institutional sector (1970-2010). The dashed lines mark election years.

In figure 5 we present the Net Lending-Net Borrowing position of the three main sectors of the Greek economy: the domestic private sector, the government sector and the foreign sector; some interesting observations can be made. First of all, in the period until the late 1990s the private sector was a net lender. The private sector became a net borrower for the first time-after two and a half decades - in 1999. For the period before 1999, 75\% of the government deficit is covered with domestic borrowing. The behavior of the private sector changes in the mid-1990s, when it starts a monotonic decrease of its lending which lasts until 2002. After 2002 and until the recent crisis the private sector continued to be a net borrower.

In general, the private sector in Greece only very recently started spending more than it earned. This observation runs contrary to the usual stereotype of widespread general profligacy. This is confirmed with a quick comparison with other countries of the euro area. In figure 6 we present the 


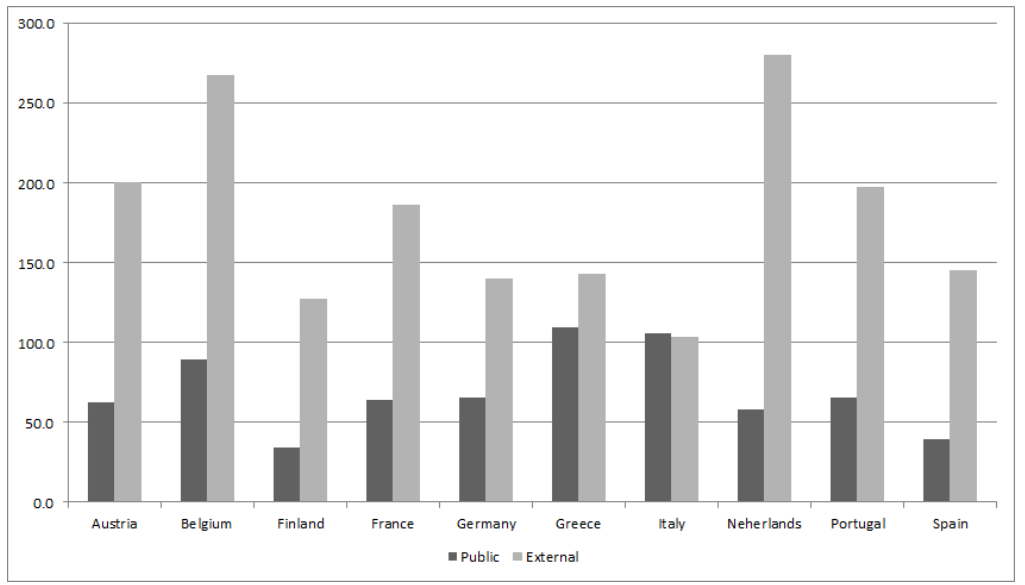

Figure 6: Public and External Debt for the year 2008 (\% GDP)

stock of public and the foreign (public and private) debt for selected countries of the Euro-area for the year 2008; after one decade of net borrowing on behalf of the Greek private sector. What we can see is that, although the public debt is the highest among the ten countries, the total external debt is relatively low, and at the same level as Germany.

The monotonic increase of lending on behalf of the private sector and after 1999 of the public sector is naturally mirrored with an analogous increase of net lending from abroad. For almost a decade and a half - after 1994 until 2008 - there is a constant increase of net lending from abroad, which compensates for the borrowing of the private and the public sector. Note that the discussion until now does not involve the direction of the causality between the foreign and domestic - public and private - deficit. We simply state, as in section 2 that from an accounting point of view the net lending of the three sectors must sum to zero. We discuss the course of causality in the next section.

\section{In Search of Causality: Is there a structural break?}

The mid-1990s appear to be a turning point for the Greek economy. The patterns that had prevailed for (at least) the previous two decades seem to change. This change is probably nowhere else as evident as in the patterns of the net-lending of the institutional sectors of the Greek economy we just described.

The change does not seem to be accidental. It coincides with the monetary unification process which started with the signing of the Maastricht Treaty on 7 February 1992 and ended with the circulation of the euro on 1 January 2002.In addition to the general Maastricht criteria for inflation, deficits and interest rates, the unification required the rapid deregulation of the financial system and the removal of the restrictions on capital account transactions. The controls on long-term capital 
movements were lifted in March of 1993 and on short-term capital movements in May of $1994 .^{8}$

Moreover, as we mentioned in section 3.4 above, the main policy target according to the Maastricht Treaty was to contain inflation. In 1995 governor of the Bank of Greece (BoG) announced that the main objective of the BoG would be a further decrease in inflation; the inflation rate had already been halved in the previous 4 years. Towards that goal, the BoG announced for the first time a specific exchange rate target. This was the so-called hard-drachma policy. More precisely, the BoG set as an intermediate target to limit the year-on-year depreciation of the drachma against ECU to $3 \%$.

The hard-drachma policy rationale is explained in a paper written by the deputy director and the research director of the Bank of Greece six years later, after the successful entry in the Eurozone (Garganas and Tavlas 2001). They argue that "by pegging the exchange rate to the currency of a low-inflation country, inflation could be brought down rapidly, because (1) the traded goods component of the price level can be stabilised, (2) of the attendant restraint imposed on wage-setting and price-setting behaviour, and (3) of the restraint imposed on aggregate demand, especially government spending" (Garganas and Tavlas 2001, p.66). ${ }^{9}$ It is obvious that an exchange rate policy that focuses on the achievement of low inflation tends to overvalue the currency.

Three years later, on March 161998 the drachma joined the Exchange Rate Mechanism (ERM) of the European Monetary System (EMS) at a central rate against ECU, which implied a depreciation of $12.3 \%$. The depreciation reduced the current account deficit momentarily (see figure 7), but did not change the overall trend. Finally, on 1 January 2001 Greece was admitted into the euro area.

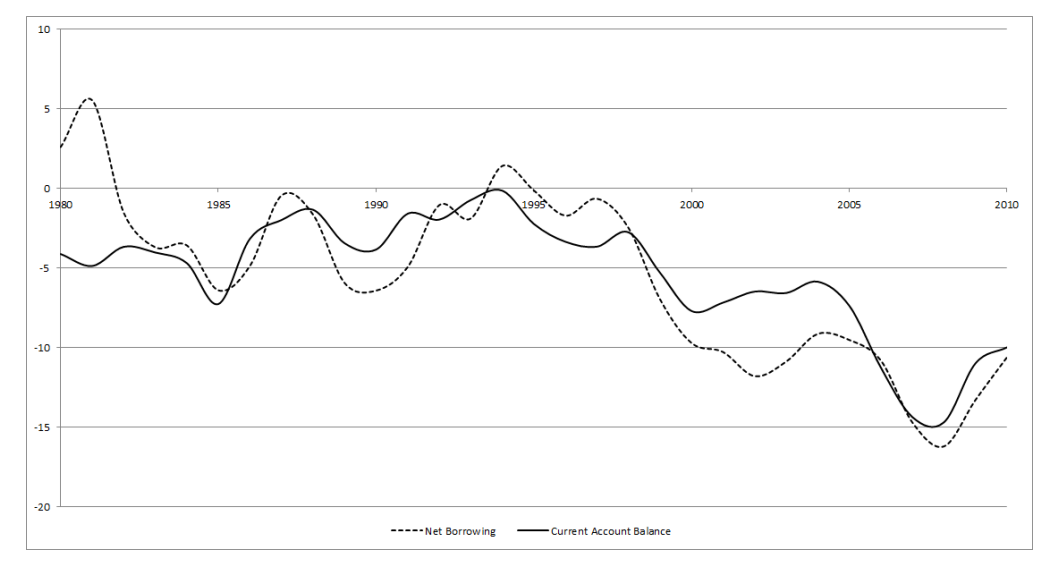

Figure 7: Current Account Balance and Net Borrowing (\% GDP)

Based on the discussion so far we can formulate the following hypothesis about the relation between public and foreign deficits: The direction of the causality between the public and foreign deficit changes in the period under examination. We can distinguish two different sub-periods:

\footnotetext{
${ }^{8} \mathrm{~A}$ detailed list of the changes in the regulation of the financial system is provided in the Appendix 1 of Garganas and Tavlas (2001).

${ }^{9}$ Their analysis is based on the 1997 World Economic Outlook of the IMF entitled "Exchange Rate Arrangements and Economic Performance in Developing Countries(International Monetary Fund 1997).
} 
Period 1980-1994: In this period the government deficit is exogenous. The high yields of the government issued securities attract savings from the private and the foreign sector. Thus, in this period the causality between the government and the foreign deficit runs from the former to the latter.

Period 1995-2010: In this second period the hard drachma policy and subsequently the introduction of the euro reverse the causality. The foreign deficit becomes (quasi-)exogenous and drives the domestic deficit, public and private. The domestic deficits were sustained for almost one and a half decades because of the general euphoria in the financial markets globally that period and the capital flows towards Greece. These flows had been made possible with the deregulation of the financial sector in 1994.

We examine the assumption about the change in the causality between the government and foreign deficit in detail in the next section using various statistical methods. However, before proceeding two comments are in order. First, a closer examination of figure 5 gives a first confirmation of our hypothesis. As we mentioned above, the government deficit picks up the election years, especially in the first period - 1981, 1985, 1989, 1990 and 1993. In the second period we have similar peaks in 2004 and 2009. The elections can be considered as an exogenous cause of the government deficits. During the first period, the increase in the government deficit is mirrored with an increase in net lending from abroad. This relationship disappears in the second period. The increased deficits of 2004 and 2009 were not mirrored by an increase in the foreign deficit; on the contrary the foreign deficit decreases in both years. ${ }^{10}$

Second, the year 1995 has been identified as a switching point for the Greek economy before and is in fact a common conclusion in the literature. Bryant et al. (2001), in a volume which celebrates the entrance of Greece in the common currency, point to the regime change of $1995 .{ }^{11}$ They write that "the performance of the Greek economy in the second half of the 1990s contrasts starkly with the performance during 1975-1994" (p. 3).

Other contributions in the same volume make similar points. Garganas and Tavlas (2001) also identify 1995 as a turning point for the Greek economy. Their focus-as deputy director and the research director of the $\mathrm{BoG}$ - is inflation. They argue that two different regimes can be distinguished: one for the period 1975-1990 with high inflation and unsatisfactory macroeconomic performance, and one for the period after 1995 with low inflation and accelerated growth. The period in-between is identified as a transition period. They test and verify their hypothesis with various statistical tests. For example, they test the hypothesis of a regime change in inflation with the Zivot and Andrews (1992) test. The test allows for an endogenous determination of the time of the regime switch. Us-

\footnotetext{
${ }^{10} \mathrm{An}$ exception to this pattern in the first period is 1981. However, figure 7 shows that although net borrowing from abroad decreased, the current account deficit increased. It is the only year with such a big discrepancy between them (probably due to some capital transfers related to the entry of Greece in the European Economic Community the year before).

${ }^{11}$ The volume is the product of collaboration between the Bank of Greece and the Brookings Institution.
} 
ing data between 1979 and 1999 they find that the regime switch took place in 1994. Bosworth and Kollintzas (2001) approach the macroeconomic performance of the Greek economy from a growthaccounting point of view and they reach a similar conclusion.

Finally, in the aforementioned papers it becomes clear that the Greek policy makers were aware of the pressure of this regime change on the current account. However, they believed in the merits of low inflation, the ability of the market to self-regulate itself, the use of the capital inflows for productive purposes and the ability of "prudential supervision" and "surveillance" on behalf of the policy makers. The mantra of the day was that "this rate of growth [during the period 1995-2001] should be sustainable in future years" and that "one might hope that the Greek experience would more closely follow that of Ireland"(Bosworth and Kollintzas 2001, p. 177-178).

\section{Econometric analysis}

\subsection{Data}

The challenge of analyzing the Greek economy econometrically is data availability and reliability, especially for quarterly data. Hence, we briefly discuss how our data set used for the econometric analysis below has been generated. We use quarterly data for the following variables from 1980Q1 to $2010 \mathrm{Q} 4$.

The real trade balance $\left(n_{t}\right)$ has been computed using data on the trade balance provided by the IMF Balance of Payments database and the GDP deflator obtained implicitly based on the Real and Nominal GDP series provided in the OECD Economic Outlook Database. The trade balance has been seasonally adjusted.

The real primary deficit $\left(d_{t}\right)$ has been more difficult to generate. Again the GDP deflator has been used to deflate the primary deficit, which was obtained from two different sources. Until 1998Q4 we employ data provided by the OECD Economic Outlook Database (which has been discontinued in 2005). For the period thereafter, we use Eurostat data which have been seasonally adjusted.

\subsection{Granger Causality}

To gain some preliminary insights into causalities between the trade surplus and the primary deficit, we apply Granger Causality tests. The idea behind this test is to check wheather a variable $y_{t}$ can help forecast another variable $x_{t}$. " $y_{t}$ fails to Granger-cause $x_{t}$ if for all $s>0$ the mean squared error of a forcast of $x_{t+s}$ based on $\left(x_{t}, x_{t-1}, \ldots\right)$ is the same as the MSE of a forecast of $x_{t+s}$ that uses both $\left(x_{t}, x_{t-1}, \ldots\right)$ and $\left(y_{t}, y_{t-1}, \ldots\right)$." Hamilton $(1994$, p. 303). Characterizing the variables by a VAR of order $p$, the coefficient matrices will be lower triangular if $y_{t}$ does not Granger-cause $x_{t}$, i.e. 


\begin{tabular}{lccccccccc}
\hline & \multicolumn{2}{c}{ 1980Q1-2010Q4 } & \multicolumn{3}{c}{ 1980Q1-1994Q4 } & \multicolumn{2}{c}{ 1995Q1-2010Q4 } \\
\hline Null Hypothesis & Obs & F-Stat. & Prob. & Obs & F-Stat. & Prob. & Obs & F-Stat. & Prob. \\
\hline 2 lags & & & & & & & & & \\
d does not GC $n_{t}$ & 122 & 3.39 & 0.037 & 58 & 0.43 & 0.653 & 64 & 1.41 & 0.252 \\
$n_{t}$ does not GC $d_{t}$ & & 6.45 & 0.002 & & 4.02 & 0.023 & & 12.55 & 0.000 \\
3 lags & & & & & & & & & \\
$d_{t}$ does not GC $n_{t}$ & 121 & 2.21 & 0.091 & 57 & 0.35 & 0.789 & 64 & 1.11 & 0.351 \\
$n_{t}$ does not GC $d_{t}$ & & 4.87 & 0.003 & & 0.81 & 0.492 & & 10.14 & 0.000 \\
4 lags & & & & & & & & & \\
$d_{t}$ does not GC $n_{t}$ & 120 & 2.10 & 0.086 & 56 & 0.40 & 0.804 & 64 & 0.93 & 0.452 \\
$n_{t}$ does not GC $d_{t}$ & & 3.56 & 0.009 & & 1.58 & 0.194 & & 8.00 & 0.000 \\
\hline
\end{tabular}

Table 1: Granger Causality tests for different lag lengths and sub-periods

$$
\left[\begin{array}{l}
x_{t} \\
y_{t}
\end{array}\right]=\left[\begin{array}{l}
c_{1} \\
c_{2}
\end{array}\right]+\left[\begin{array}{cc}
\phi_{11}^{(1)} & 0 \\
\phi_{21}^{(1)} & \phi_{22}^{(1)}
\end{array}\right]\left[\begin{array}{l}
x_{t-1} \\
y_{t-1}
\end{array}\right]+\left[\begin{array}{cc}
\phi_{11}^{(2)} & 0 \\
\phi_{21}^{(2)} & \phi_{22}^{(2)}
\end{array}\right]\left[\begin{array}{l}
x_{t-2} \\
y_{t-2}
\end{array}\right]+\ldots+\left[\begin{array}{cc}
\phi_{11}^{(p)} & 0 \\
\phi_{21}^{(p)} & \phi_{22}^{(p)}
\end{array}\right]\left[\begin{array}{l}
x_{t-p} \\
y_{t-p}
\end{array}\right]+\left[\begin{array}{l}
\varepsilon_{1 t} \\
\varepsilon_{2 t}
\end{array}\right]
$$

To test whether $y_{t}$ does not Granger-cause $x_{t}$ we can simply perform an F-test of the null hypothesis, $H_{0}: \phi_{12}^{(1)}=\phi_{12}^{(2)}=\ldots=\phi_{12}^{(p)}=0$ (cf. Hamilton 1994). We check robustness by considering different lag lengths $p$.

Table 1 reports the results for testing Granger Causality between $n_{t}$ and $d_{t}$ for the total sample and for the two sub-periods before and after 1995. We obtain the following results:

Averaging over the total period 1980Q1-2010Q4, we cannot reject, at the 5\% significance level, the hypothesis that the primary deficit does not Granger-cause the trade balance for lag lengths of 3 and 4 even though the respective p-values are low. On average over the entire sample, therefore, there seems to exist some evidence that the primary deficit affects the trade balance. Stronger evidence exists, however, supporting the reversed causality. For the same sample we can confidently reject the null that the trade deficit does not Granger-cause the primary deficit for all lag lengths. The trade balance seems to have a highly significant effect on the primary deficit.

For the sub-period 1980Q1-1994Q4, we cannot reject either of the null hypotheses for most of the lag lengths. This suggests that none of the variables seem to have affected each other in the first period.

Yet, this picture changes radically in the period 1995Q1-2010Q. While the null of the primary deficit not Granger-causing the trade balance cannot be rejected, the null of the trade balance not Granger-causing the primary deficit can be rejected at a high level of significance. Hence, it seems that in the second period the trade balance has been driving the primary deficit but not the over way around. This result is robust to the lag length chosen. 


\subsection{Cointegrated Vector-Autoregression Analysis}

Granger Causality tests can only provide preliminary insights as the forward-looking behavior of agents allows for an event $\mathrm{X}$ to be realized before another event $\mathrm{Y}$ even though $\mathrm{Y}$ is the true cause of X. Yet, the Granger Causality test will indicate that $\mathrm{Y}$ fails to Granger-Cause $\mathrm{X}$, as $\mathrm{Y}$ is realized after $\mathrm{X}$ in time. To check the robustness of the results above by another methhod, we analyze the interaction of $n_{t}$ and $d_{t}$ in a Vector-Autoregression (VAR) model. As the baseline specification, we estimate the following VAR in Vector-Error-Correction Model (VECM) representation:

$$
\Delta x_{t}=\alpha\left[\begin{array}{lll}
\beta^{\prime} & \beta_{0} & \beta_{1}
\end{array}\right]\left[\begin{array}{c}
x_{t-1} \\
c \\
t
\end{array}\right]+\sum_{i=1}^{k-1} \Gamma_{i} \Delta x_{t-1}+\Phi D_{t}+\varepsilon_{t}
$$

where $x_{t}=\left[\begin{array}{ll}n_{t} & d_{t}\end{array}\right]^{\prime}, D_{t}$ is a matrix of deterministic variables and $\varepsilon_{t} \sim I N_{p}(0, \Omega)$ is a vector of disturbances. We include a constant term as well as a trend, the latter only in the cointegrating space. We chose $k=2$ as the optimal lag length according to the H-Q criterion (analyzed in CATS for RATS) applied to the baseline model. No more lags are required since there is generally no problems with serial correlation in the residuals. We stick to the choice of two lags also when considering extensions of the baseline specification in order to be as comparable as possible. Only if autocorrelation problems arise (which is almost never the case) adding additional lags is considered as an option to deal with the problem.

There is an issue with the choice of the deterministic variables such as trends, constants and dummies in the model. Looking at the residuals generally reveals in our study that dummy variables for instance capturing the financial crisis do not seem to be required. This leaves the question of how to correctly restrict trends and constants in the model. Since there is no trend in the data and there is no plausible explanation for expecting one in the cointegrating relation between the trade balance and the primary deficit, a trend should be excluded from the model. Yet, sometimes the trace test will not be able to identify the cointegrating relationship if the trend is excluded. Therefore, it might be necessary to include a trend in all specifications to identify the cointegrating relationship in all of them and make them consistent to each other.

\subsubsection{Rank test}

Table 2 reports the rank test statistics for the total period and the periods before and after 1995 for specifications with or without the time trend. According to the trace test, we can accept the hypothesis of $r=1$ for almost all sub-samples regardless of whether a time trend has been included or not. ${ }^{12}$

\footnotetext{
${ }^{12}$ The only exception is the trace test for the specification with time trend for the period from 1980Q1 to 1994Q4, which indicates no cointegration relation.
} 


\begin{tabular}{|c|c|c|c|c|c|c|c|c|c|}
\hline & \multicolumn{3}{|c|}{ 1980Q1-2010Q4 } & \multicolumn{3}{|c|}{ 1980Q1-1994Q4 } & \multicolumn{3}{|c|}{ 1980Q1-2010Q4 } \\
\hline No. of CE(s) & EV & TS. & Prob. & EV & TS & Prob. & EV & TS & Prob. \\
\hline None * & 0.20 & 36.53 & 0.001 & 0.18 & 19.19 & 0.269 & 0.29 & 30.83 & 0.011 \\
\hline At most 1 & 0.07 & 8.84 & 0.190 & 0.12 & 7.78 & 0.269 & 0.12 & 8.39 & 0.220 \\
\hline No. of CE(s) & EV & TS & Prob. & EV & TS & Prob. & $\mathrm{EV}$ & TS & Prob. \\
\hline None * & 0.11 & 18.89 & 0.076 & 0.17 & 12.16 & 0.023 & 0.29 & 26.99 & 0.005 \\
\hline At most 1 & 0.03 & 4.25 & 0.376 & 0.43 & 1.34 & 0.899 & 0.06 & 4.58 & 0.331 \\
\hline
\end{tabular}

Table 2: Trace tests for different sub-periods

\begin{tabular}{|c|c|c|c|c|c|c|c|c|c|c|c|c|}
\hline & \multicolumn{4}{|c|}{ 1980Q1-2010Q4 } & \multicolumn{4}{|c|}{ 1980Q1-1994Q4 } & \multicolumn{4}{|c|}{ 1980Q1-2010Q4 } \\
\hline & $n$ & $d$ & $c$ & $t$ & $n$ & $d$ & $c$ & $t$ & $n$ & $d$ & $c$ & $t$ \\
\hline \multicolumn{13}{|c|}{ The cointegrating relations $\boldsymbol{\beta}$} \\
\hline $\boldsymbol{\beta}_{1}^{\prime}$ & 1.00 & $\begin{array}{c}0.58 \\
{[4.46]}\end{array}$ & 900.57 & $\begin{array}{l}44.61 \\
{[9.84]}\end{array}$ & 1.00 & $\begin{array}{l}-0.17 \\
{[-0.96]}\end{array}$ & 2424.30 & $\begin{array}{l}8.21 \\
{[1.39]}\end{array}$ & 1.00 & $\begin{array}{c}0.70 \\
{[2.65]}\end{array}$ & 2083.68 & $\begin{array}{l}33.71 \\
{[1.54]}\end{array}$ \\
\hline \multicolumn{13}{|c|}{ The adjustment coefficients $\boldsymbol{\alpha}$} \\
\hline $\boldsymbol{\alpha}_{1}^{\prime}$ & $\begin{array}{l}-0.04 \\
{[-0.95]}\end{array}$ & $\begin{array}{c}-0.24 \\
{[-5.39]}\end{array}$ & & & $\begin{array}{l}-0.51 \\
{[-3.05]}\end{array}$ & $\begin{array}{c}0.03 \\
{[0.78]}\end{array}$ & & & $\begin{array}{l}-0.04 \\
{[-0.75]}\end{array}$ & $\begin{array}{l}-0.30 \\
{[-4.89]}\end{array}$ & & \\
\hline & $n$ & $d$ & $c$ & $t$ & $n$ & $d$ & $c$ & $t$ & $n$ & $d$ & $c$ & $t$ \\
\hline \multicolumn{13}{|c|}{ The cointegrating relations $\boldsymbol{\beta}$} \\
\hline $\boldsymbol{\beta}_{1}^{\prime}$ & 1.00 & $\begin{array}{l}4.47 \\
{[3.84]}\end{array}$ & $\begin{array}{l}823.08 \\
{[0.53]}\end{array}$ & - & 1.00 & $\begin{array}{l}-0.34 \\
{[-1.91]}\end{array}$ & $\begin{array}{c}2813.66 \\
{[15.42]}\end{array}$ & - & 1.00 & $\begin{array}{l}1.20 \\
{[6.33]}\end{array}$ & $\begin{array}{c}4716.16 \\
{[16.17]}\end{array}$ & - \\
\hline \multicolumn{13}{|c|}{ The adjustment coefficients $\boldsymbol{\alpha}$} \\
\hline $\boldsymbol{\alpha}_{1}^{\prime}$ & $\begin{array}{l}0.01 \\
{[1.49]}\end{array}$ & $\begin{array}{l}-0.02 \\
{[-3.34]}\end{array}$ & & & $\begin{array}{l}-0.36 \\
{[-2.29]}\end{array}$ & $\begin{array}{c}0.07 \\
{[1.78]}\end{array}$ & & & $\begin{array}{l}-0.01 \\
{[-0.30]}\end{array}$ & $\begin{array}{l}-0.23 \\
{[-4.97]}\end{array}$ & & \\
\hline
\end{tabular}

Table 3: Estimation results for different sub-periods

\subsubsection{Testing restrictions on $\alpha$ and $\beta^{\prime}$}

Before discussing the estimation results from fitting the model in (10) to the data, note that we tested for serial correlation in the residuals for each of the periods considered. We cannot reject the hypotheses of no serial correlation of the residuals up to order 3 at any reasonable level of significance.

Table 3 reports the estimates of $\boldsymbol{\alpha}$ and $\boldsymbol{\beta}^{\prime}$ in (10) for the total period as well as for the periods before and after 1995. We consider both specifications, including and excluding a time trend. Note that no over-identifying restrictions are imposed. For each sample, the cointegrating vector, $\boldsymbol{\beta}^{\prime}$, has been normalized to $n$.

Averaging over the entire sample, $n$ and $d$ are inversely related in the long run. For the specification including the time trend, the estimated parameter for an adjustment of $n$ to a disequilibrium is not error-correcting as the point estimate, -0.04 , is negative. In other words, with this parameter a disequilibrium in the long-run relation would cause $n$ to change such that the disequilibrium was aggravated. The estimate of 0.01 for the specification without time trend, implies the adjustment parameter characterizing the response of $n$ to a one unit disequilibrium in the cointegrating relation to be error-correcting. That means, a disequilibrium will be mitigated by a conform change in $n$. However, the parameter estimates are insignificant in both cases. We cannot reject the null hypothesis that the trade balance does not respond to a disequilibrium in the cointegrating relation for either specification. Hence, the trade balance seems to be weakly exogenous over the total period. Yet, the 
parameter describing the adjustment of $d$ to a disequilibrium in the long-run relation is significant in both cases. A disequilibrium in the cointegrating space of one unit leads to an adjustment of the primary deficit by -0.24 in the specification with trend and by -0.02 in the specification without trend, in both cases reducing the disequilibrium.

Considering the period before and after 1995 reveals some interesting differences between the sub-samples. While the long-run relationship between $n$ and $d$ is postive and insignificant before 1995 , it is negative and significant thereafter for both specifications. In the first period, $d$ is weakly exogenous, i.e. it does not respond to a disequilibrium. The adjustment of $n$ to a disequilibrium is significant but not error-correcting since it has the wrong sign. In the second period, $n$ is weakly exogenous while the adjustment of $d$ to a disequilibrium is significant and error-correcting. This finding is highly consistent with the results of the Granger-Causality tests. Since 1995 it seems that the the trade balance has been driving the primary deficit.

\section{Concluding remarks}

Our econometric results confirm the hypothesis that the causality between the trade deficit and public deficit in Greece reversed around 1995, running from the former to the latter since then. The mid 1990s mark the beginning of a sharp deterioration of the external position of the Greek economy, which lasts until 2009. Not surprisingly the biggest part of this deterioration comes from the current account. The policy of the hard drachma and later the introduction of the euro, put pressure on the foreign sector. In this period the behavior of the foreign sector obtains an autonomous status. The increasingly high foreign deficits are now the cause of the deficits in the domestic sector. These deficits in turn become possible because of the liberalization of the capital accounts, the massive capital inflows and the very low interest rates. The causality between the government and the foreign deficit is running from the latter to the former.

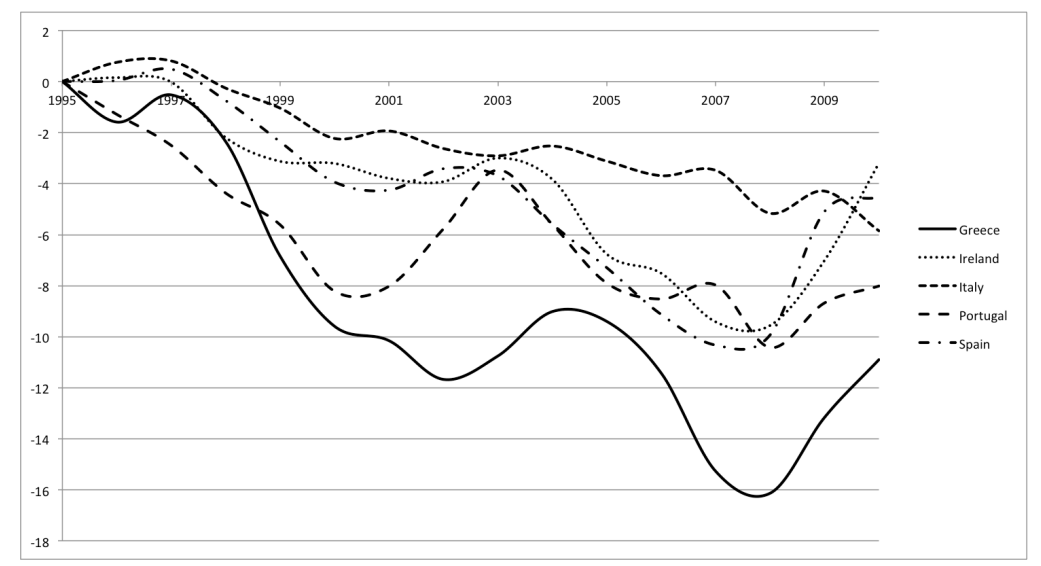

Figure 8: Net Borrowing in the peripheral euro-area countries(\% GDP, 1995=0) 


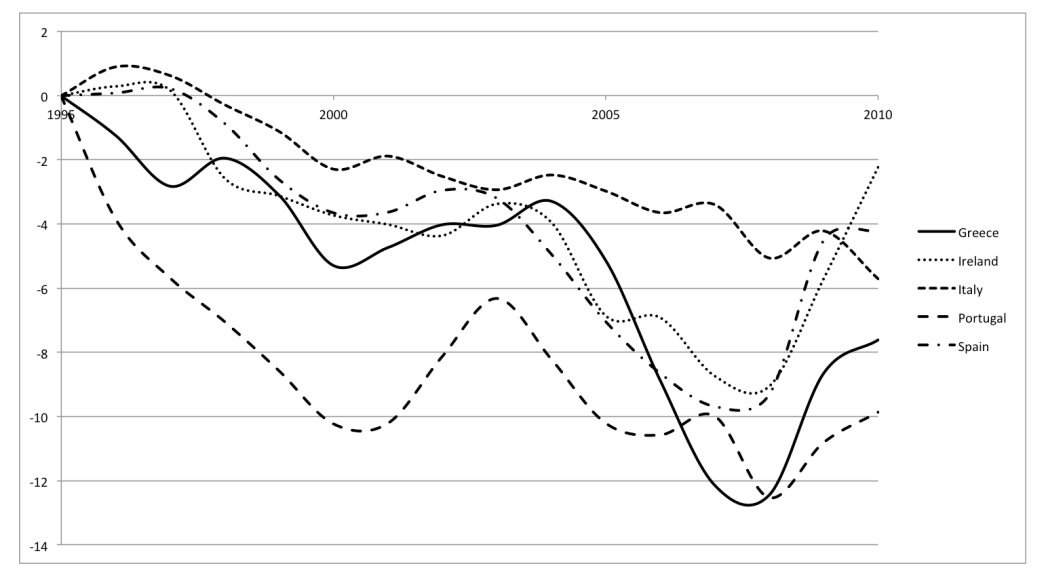

Figure 9: Current Account Balance in the peripheral euro-area countries(\% GDP, 1995=0)

This conclusion is reinforced when one compares the trajectory of the net lending position and the current account balance of Greece with the rest of the Euro-area peripheral economies. We present these series in figures 8 and 9 respectively, normalized to zero for the year 1995. It is clear that in the period since 1995 and until the recent crisis the external position of all five peripheral countries of the euro area deteriorated significantly. Between the years 1995 and 2008 the current account of Greece and Portugal worsened by around 11 percentage points of GDP, while in the cases of Spain and Ireland this number is around 9.5\%. Italy did relatively better and lost only 6 percentage points in the period 1995-2010.

Of course, the stories of the five peripheral countries are not identical. In the case of Portugal, Spain and Ireland it was the private sector that carried the weight of adjustment to this worsening foreign position. The Italian case is more similar to the Greek one. However, the common denominator in all five cases is the increasing foreign deficit and borrowing. This finding emphasizes the structural imbalances within the euro area as the main cause of the crisis.

From a policy point of view, if the causality runs this way, the best way to fight fiscal deficits is to decrease the foreign deficits. In that sense, a European "Current Account Compact" would be more appropriate than the recent European Fiscal Compact. 


\section{References}

Abell, J. D. (1990). Twin deficits during the 1980s: an empirical investigation. Journal of Macroeconomics, 12(1):81-96.

Baharumshah, A. Z., Lau, E., and Khalid, A. M. (2006). Testing the twin deficits hypothesis using vars and variance decomposition. Journal of the Asia Pacific Economy, 11:331-354.

Barbosa-Filho, N., von Arnim, C. R., Taylor, L., and Zamparelli, L. (2008). Cycles and trends in u.s. net borrowing flows. Journal of Post Keynesian Economics, 30(4):623 - 648.

Barro, R. J. (1974). Are government bonds net wealth? The Journal of Political Economy, 82(6):pp. 1095-1117.

Barro, R. J. and Gordon, D. B. (1983). Rules, discretion and reputation in a model of monetary policy. Journal of Monetary Economics, 12(1):101-121.

Betts, C. and Devereux, M. B. (2000). Exchange rate dynamics in a model of pricing-to-market. Journal of International Economics, 50(1):215-244.

Bosworth, B. and Kollintzas, T. (2001). Economic Growth in Greece: Past Performance and Future Prospects. In Greece's Economic Performance and Prospects. Bank of Greece and The Brookings Institution, Athens, Greece and Washington, D.C.

Bryant, R. C., Garganas, N. C., and Tavlas, G. S., editors (2001). Greece's Economic Performance and Future Prospects. Bank of Greece and The Brookings Institution, Athens, Greece and Washington, D.C.

CES-IFO (2011). Net Interest Payments, General Government, as a Percentage of Nominal GDP, 1960 - 2012. http://www. cesifo-group.de/portal/page/portal/ifoHome/a-winfo/ d3iiv/_DICE_details?_id=6746946\&_thid=15548538\&_cat=c.

Corsetti, G. and Muller, G. J. (2005). Twin deficits: Squaring theory, evidence and common sense. Economics Working Papers ECO2005/22, European University Institute.

De Grauwe, P. (2012). Economics of Monetary Union. Oxford University Press, Oxford, UK.

DG ECFIN (2011). European Commission, Directorate General for Economic and Financial Affairs, Annual macro-economic database (AMECO). Data retrieved December 5, 2011. http://ec . europa.eu/economy_finance/ameco. 
Erceg, C. J., Guerrieri, L., and Gust, C. (2005). Expansionary fiscal shocks and the us trade deficit*. International Finance, 8(3):363-397.

Federal Reserve (2013). Board of Governors of the Federal Reserve System,Selected Interest Rates. Data retrieved January 24, 2013. http: //www . federalreserve.gov/releases/h15/.

Garganas, N. C. and Tavlas, G. S. (2001). Monetary Regimes and Inflation Performance: The Case of Greece. In Greece's Economic Performance and Prospects. Bank of Greece and The Brookings Institution, Athens, Greece and Washington, D.C.

Godley, W. and Cripps, F. (1983). Macroeconomics. Oxford University Press, New York.

Hamilton, J. D. (1994). Time Series Analysis. Princeton University Press, Princeton.

IMF (1999). Balance of payments manual. Statistics department, International Monetary Fund.

International Monetary Fund (1997). World Economic Outlook (WEO). available online at http: //www.imf .org/external/pubs/ft/weo/weo1097/weocon97.HTM.

International Monetary Fund (2012). World Economic Outlook (WEO): Growth Resuming, Dangers Remain. available online at http://www.imf .org/external/pubs/ft/weo/2012/01/index. htm.

Kenen, P. (1969). The Theory of Optimum Currency Areas: An Eclectic View. In Mundell, R. A. and Swoboda, A. K., editors, Monetary Problems of the International Economy. Chicago University Press, Chicago, IL.

Kim, S. and Roubini, N. (2008). Twin deficit or twin divergence? fiscal policy, current account, and real exchange rate in the u.s. Journal of International Economics, 74(2):362 - 383.

Krugman, P. (2012). Revenge of the Optimum Currency Area. In Acemoglu, D., Parker, J., and Woodford, M., editors, NBER Macroeconomics Annual 2012, volume 27. University of Chicago Press, Chicago, IL.

Kydland, F. E. and Prescott, E. C. (1977). Rules rather than discretion: The inconsistency of optimal plans. The Journal of Political Economy, 85(3):pp. 473-492.

Mundell, R. A. (1961). A Theory of Optimum Currency Areas. The American Economic Review, 51(4):657-665.

Obstfeld, M. and Rogoff, K. (1995). Exchange rate dynamics redux. Journal of Political Economy, 103(3):624-660. 
Obstfeld, M. and Rogoff, K. (1996). Foundations of International Macroeconomics. The MIT Press, Cambridge, MA.

OECD (2011a). Organisation for Economic Co-operation and Development, Economic Outlook Database. Data retrieved December 5, 2011. http://www . oecd-ilibrary .org/.

OECD (2011b). Organisation for Economic Co-operation and Development, OECD.Stat Extracts. Data retrieved December 5, 2011. http://stats . oecd.org/Index . aspx.

Reinhart, C. and Rogoff, K. (2010). Growth in a time of debt. American Economic Review, 100(2):573-578.

Salvatore, D. (2006). Twin deficits in the g-7 countries and global structural imbalances. Journal of Policy Modeling, 28:701-712.

Schneider, F. (2011). The Shadow Economy and Shadow Economy Labor Force: What Do We (Not) Know. Discussion Paper No. 576, Institute for the Study of Labor.

Steindl, J. (1990). Saving and debt. In Economic Papers 1941-88., pages 208-215. Macmillan.

Summers, L. H. (1988). Tax policy and international competitiveness. In Frenkel, J., editor, International aspects of fiscal policies, pages 349-375. Chicago University Press, Chicago.

Taylor, L. (1994). Gap models. Journal of Development Economics, 45:17-34.

Taylor, L. and Lysy, F. J. (1979). Vanishing income redistributions: Keynesian clues about model surprises in the short run. Journal of Development Economics, , 6(1):11-29.

Thirlwall, A. P. and Hussain, M. N. (1982). The balance of payments constraint, capital flows and growth rate differences between developing countries. Oxford Economic Papers, 34(3):498-510.

Vamvoukas, G. A. (1999). The twin deficits phenomenon: evidence from greece. Applied Economics, 31:1093-1100.

Volcker, P. A. (1984). Facing up to the twin deficits. Challenge 3.

World Bank Group (2011). World development indicators online. Data retrieved December 5, 2011. http://data. worldbank.org/data-catalog/world-development-indicators.

Zivot, E. and Andrews, D. W. K. (1992). Further Evidence on the Great Crash, the Oil-Price Shock, and the Unit-Root Hypothesis. Journal of Business \& Economic Statistics, 10(3):251-270. 


\section{Appendix}

\section{Data sources for section 3}

Figure 1: World Development Indicators (World Bank Group 2011)

Figure 2: The data for the government deficit until 1998 were retrieved from the OECD Economic Outlook (OECD 2011a) and the rest of the series from the Annual macro-economic database (AMECO) of the European Commission's Directorate General for Economic and Financial Affairs (DG ECFIN 2011). The data for the net interest payments were retrieved from CES-IFO (2011) and the primary deficit was calculated as a residual.

Figure 3: The implicit interest rate was calculated based on equation (6) and the data for debt as a percentage of GDP and the net interest payments of figure 1 and 2. The data for the FED interest rate were retrieved from the website of the Federal Reserve (2013).

Figure 4: World Development Indicators (World Bank Group 2011)

Figure 5: The data for the Net Lending-Net Borrowing of the foreign sector were retrieved from "Disposable income and net lending - net borrowing" series from the OECD.Stat Extracts database (OECD 2011b). The Net Lending-Net Borrowing position was calculated residually so as the accounting identity (that the sum of the net lending positions of the three sectors is equal to zero) is satisfied.

Figure 6: Database of Reinhart and Rogoff (2010). The data can be accessed online at http:// wWw. reinhartandrogoff.com/.

Figure 7:The data for the current account come from the 2012 World Economic Outlook of the International Monetary Fund (2012).

Figure 8: The data for the Net Lending-Net Borrowing of the foreign sector were retrieved from "Disposable income and net lending - net borrowing" series from the OECD.Stat Extracts database (OECD 2011b).

Figure 9: The data for the current account come from the 2012 World Economic Outlook of the International Monetary Fund (2012). 